Article

\title{
Comparing Manual and Semi-Automated Landslide Mapping Based on Optical Satellite Images from Different Sensors
}

\author{
Daniel Hölbling ${ }^{1, *}$, Clemens Eisank ${ }^{2}$, Florian Albrecht ${ }^{1}$, Filippo Vecchiotti ${ }^{3}$, Barbara Friedl ${ }^{1}$, \\ Elisabeth Weinke ${ }^{1}$ and Arben Kociu ${ }^{3}$ \\ 1 Department of Geoinformatics-Z_GIS, University of Salzburg, Schillerstrasse 30, 5020 Salzburg, Austria; \\ florian.albrecht@sbg.ac.at (F.A.); barbara.friedl@sbg.ac.at (B.F.); elisabeth.weinke@sbg.ac.at (E.W.) \\ 2 GRID-IT-Gesellschaft für angewandte Geoinformatik mbH, Technikerstraße 21a, 6020 Innsbruck, Austria; \\ eisank@grid-it.at \\ 3 Geological Survey of Austria (GBA), Neulinggasse 38, 1030 Vienna, Austria; \\ filippo.vecchiotti@geologie.ac.at (F.V.); arben.kociu@geologie.ac.at (A.K.) \\ * Correspondence: daniel.hoelbling@sbg.ac.at; Tel.: +43-662-8044-7581
}

Academic Editors: Francesca Cigna and Jesus Martinez-Frias

Received: 31 March 2017; Accepted: 11 May 2017; Published: 19 May 2017

\begin{abstract}
Object-based image analysis (OBIA) has been increasingly used to map geohazards such as landslides on optical satellite images. OBIA shows various advantages over traditional image analysis methods due to its potential for considering various properties of segmentation-derived image objects (spectral, spatial, contextual, and textural) for classification. For accurately identifying and mapping landslides, however, visual image interpretation is still the most widely used method. The major question therefore is if semi-automated methods such as OBIA can achieve results of comparable quality in contrast to visual image interpretation. In this paper we apply OBIA for detecting and delineating landslides in five selected study areas in Austria and Italy using optical Earth Observation (EO) data from different sensors (Landsat 7, SPOT-5, WorldView-2/3, and Sentinel-2) and compare the OBIA mapping results to outcomes from visual image interpretation. A detailed evaluation of the mapping results per study area and sensor is performed by a number of spatial accuracy metrics, and the advantages and disadvantages of the two approaches for landslide mapping on optical EO data are discussed. The analyses show that both methods produce similar results, whereby the achieved accuracy values vary between the study areas.
\end{abstract}

Keywords: landslides; remote sensing; semi-automated mapping; object-based image analysis (OBIA); manual mapping; visual interpretation; spatial accuracy metrics; Alps

\section{Introduction}

Optical Earth Observation (EO) data has proven beneficial for mapping the location and spatial extent of landslides at various spatial scales, ranging from local to regional [1]. The interpretation of optical EO data for landslide recognition may be conducted using manual, semi-automatic, and automatic approaches [2].

Traditionally, manual visual image interpretation for landslide recognition has been based on aerial photographs and recently extended to high resolution (HR) and very high resolution (VHR) optical satellite imagery (e.g., WorldView-2/3, QuickBird) [2] and is still the most widely used method for landslide detection and inventory preparation. Imagery with lower resolutions (e.g., SPOT, Landsat) has also been successfully employed for delineating single, larger landslides [3], yet VHR optical data has become the best choice for landslide recognition on the basis of landform analysis over larger 
areas [1]. The comparison between landslide maps derived from aerial images and satellite images reveals that both data sources yield results of equal value [4,5]. Manual visual image interpretation of optical imagery turned out to be practicable for landslide mapping, especially where landslides led to significant changes in the land cover, as is usually the case for shallow landslides. Shape, size, pattern, and texture with characteristic contrast in brightness (for black and white photography) or color variation (in case of a multispectral image) are used for manual landslide interpretation [6]. One major advantage related to visual image interpretation is the use of stereo-vision for landslide recognition, as some landslide features are detectable only employing the third dimension [2]. However, manual interpretation reveals several drawbacks; it is resource and time consuming and the quality of the resulting landslide maps strongly depends on the experience and skills of the investigator [7-9]. The variability in human visual interpretation tasks across time and individuals is a common but understated problem and has also been investigated for remote sensing image interpretation of features in urban areas [10], in rural areas [11], and in slums [12]. This subjectivity issue is difficult to measure, but influences the reliability of landslide mapping [13,14], which further depends on the persistence of the landslide morphology, the quality and scale of the imagery, the complexity of the geological and geomorphological setting, the presence of vegetation coverage, and the final map scale [9]. It has been recognized that, when more than one compilation of landslide inventories is closely evaluated, different operators produce unequal results in terms of the number and density of landslides, which also vary in geometry and extent $[7,8]$. Ardizzone et al. [14] compared three independently produced landslide inventory maps and conclude that the detail and precision of landslide maps primarily depend on the experience and skills of the investigator and only secondly on the quality of the remote sensing data and base maps used.

During the past decade, advances in computer science and machine intelligence and the ever increasing number of satellite missions acquiring VHR data led to the development of novel technologies, fostering the semi-automated interpretation of EO data. The current approaches can be split into two categories [1,15], pixel-based and object-based, both containing techniques applicable to single and multi-temporal images and frequently making use of additional data, e.g., digital elevation models (DEMs) [16]. Pixel-based methods take into account the spectral information associated with each pixel without considering its actual neighborhood [2]. Considering the resolution of HR/VHR data and the size and spatial distribution of landslides, pixel-based methods tend to be additionally sensitive to errors [17], frequently resulting in salt-and-pepper classifications, with single pixels being demarcated as landslides.

Due to these circumstances, there has been a trend towards object-based landslide recognition in recent years, as demonstrated by a range of studies [8,16-29]. Object-based image analysis (OBIA) provides a set of innovative tools for semi-automatically delineating and classifying landslides based on EO data. Object-based algorithms rely on the concepts of image segmentation and classification. Regarding landslide recognition, landslides or landslide features are composed of aggregations of homogeneous pixels rather than spatially uncorrelated cells and are then classified according to specific characteristics. By supporting the use of a plethora of properties during the classification process, e.g., spectral, spatial, textural, and contextual, OBIA is somewhat mimicking human perception and thereby proves its potential for producing more accurate and realistic landslide maps than pixel-based procedures $[15,17,18]$. OBIA therefore can be considered a specific type of model of the human perception process [30]. This model type performs well in producing an understandable encoding of explicit expert knowledge in rulesets for the production of repeatable image classification results, e.g., as demonstrated by Eisank et al. [31]. At the same time, OBIA is also a simplification of the human perception process and has certain disadvantages. In practice, OBIA workflows are a tradeoff between keeping a low complexity and covering all details and tend to ignore special cases in favor of generally applicable classification rules. Therefore, like manual visual image interpretation, OBIA-derived classification results are not free of error either. Consequently, the accuracy of semi-automated landslide classifications should be documented, but, at the same time, the reliability of the reference should be 
critically scrutinized. Attainable accuracy values vary considerably between studies, often due to the varying complexity and appearance of landslides. Accuracy values reach up to $95 \%$ for the detection of landslide scars and range between $73 \%$ and $93.7 \%$ for the detection of landslide-affected areas and between $44.8 \%$ and $90 \%$ for the identification of different landslide types such as debris slides, rock slides, or debris flows [15-22,25-27]. Object-based landslide mapping routines are often tailored to specific study areas and data and thus reveal a lack of transferability and robustness. Also the selection of suitable segmentation parameters for the creation of "meaningful" image objects, which in turn affects the accuracy of image classification as well as the application of user driven thresholds, remain critical issues [27].

In this study, we aim to compare the results of two independently performed landslide mapping approaches; semi-automated detection of landslides by OBIA and manual mapping of landslides. The analyses are based on optical satellite imagery obtained from different sensors, i.e., Landsat 7 , SPOT-5, WorldView-2, WorldView-3, and Sentinel-2. Based on five selected case studies in the Alps, spatial accuracy values are calculated to evaluate if the results are comparable when the same data basis is used for analyses.

\section{Materials and Methods}

\subsection{Study Areas}

Five landslide prone areas in the Alps with different geomorphic characteristics were selected as test sites for the development and comparison of the mapping approaches. Two study sites are located in the federal state of Salzburg, Austria, two in the federal state of Vorarlberg, Austria, and one in Südtirol-Alto Adige Autonomous Province, Italy (Figure 1). The Italian test site is divided into two sub-areas located in the Gader Valley.

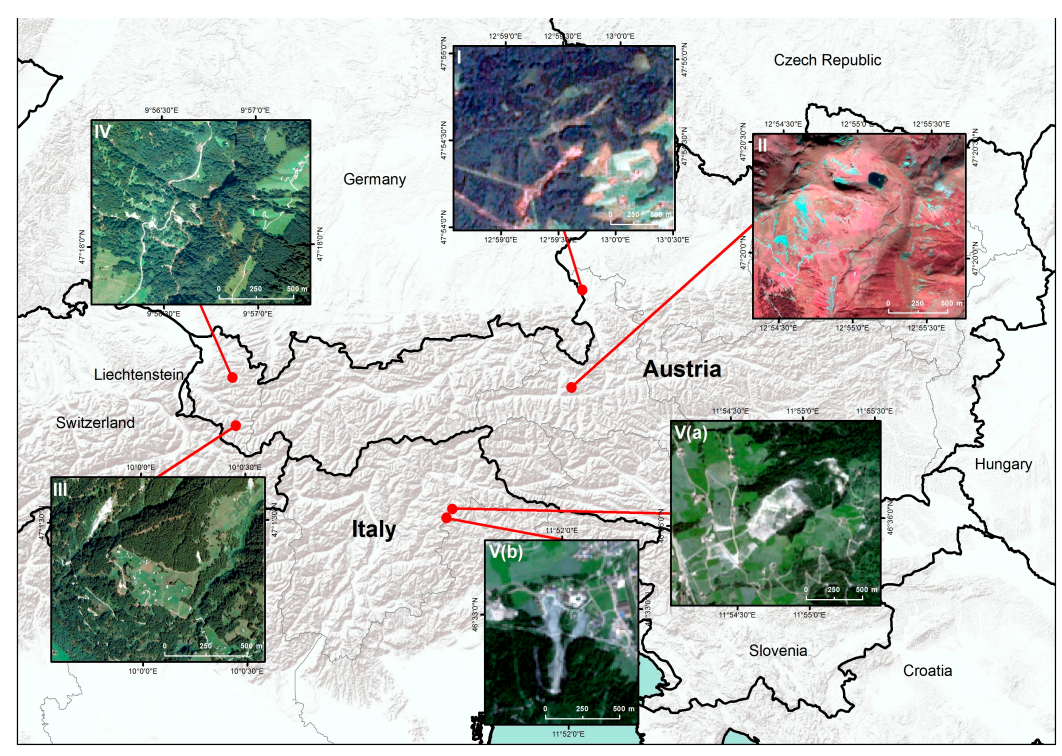

Figure 1. Study areas in Austria and Italy. Study areas I (Fürwag/Haunsberg) and II (Pinzgau) are located in the federal state of Salzburg, Austria; study areas III (Montafon) and IV (Bregenzerwald) are located in the federal state of Vorarlberg, Austria; and study area V (Gader Valley) is in Südtirol-Alto Adige Autonomous Province, Italy. The Italian study area in the Gader Valley is divided in two sub-areas $(\mathrm{V}(\mathrm{a})$ and $\mathrm{V}(\mathrm{b}))$.

\subsubsection{Study Areas I and II in the Federal State of Salzburg}

Study areas I and II (Salzburg; Figure 1) are located in a geologic domain that encompasses Quaternary until Permian units. They are respectively [32]: 
- The quaternary alluvial and moraine deposits

- The tertiary Eocene-Miocene Molasse

- $\quad$ The Jura-mid Eocene continental margin Helvetic Zone

- The Lower Cretaceous-Eocene Penninic Rhenodanubian Flysch

- $\quad$ The Permo-Mesozoic Northern Calcareous Alps (NCA)

The Permo-Mesozoic Northern Calcareous Alps were deposited in a reef-submerged environment corresponding to the opening of the Penninic Sea. At the very end of the Cretaceous Period, on the active margin of the Austroalpine microplate, as a result of the subduction, an accretionary wedge was formed, and a new deep water flysch-like deposition facies, the Rhenodanubian Flysch, took place [32].

The erosional debris of the Alpine uplift occurring between the Alpine orogenic front and the European foreland formed the tertiary Molasse. During the Würmian, the extent of the Salzach glacier reached the Inn basin to the north. The Salzach valley, an over-deepened Alpine valley, was filled mainly with lacustrine and delta sediments. The melting outlet-glacier deposited big terminal moraines, and the melt water runoff caused strong lateral erosion along the foot of the slopes, which locally provoked deep-seated gravitational slope deformations [33].

The "Fürwag Landslide" (study area I) is located at the Haunsberg, approximately $10 \mathrm{~km}$ north of the city of Salzburg, and covers an area of approximately 170 ha. The landslide-prone area consists of various mudslides, which have been formed at different times. The sandstones, shales, and the Flysch, in particular the Zementmergelserie (marl cement series), of this pre-alpine zone are very prone to mass movements [34]. The latest sliding processes occurred between 1999 and 2003, and have almost reached the valley floor, representing a constant threat to major infrastructure facilities [35].

In the Pinzgau region (study area II) the greywacke zone is especially susceptible to sliding processes. The Central Alps are dominated by different metamorphic rock types, leading to a great variety of mass movement types [34]. In June 2013 parts of this region have been declared a disaster zone due to torrential rains, which caused severe flooding and numerous landslides. A mountainous area (the Hundstein Mountain) characterized by a high relief and sparse vegetation, where several geomorphological phenomena occur, has been selected as study area in the Pinzgau region.

\subsubsection{Study Areas III and IV in the Federal State of Vorarlberg}

The major tectonic units of study areas III and IV (Vorarlberg; Figure 1), can be subdivided from North to South into three groups [36]:

- Molasse

- Helvetic Nappes and Vorarlberg Flysch (Eastern Alps origin)

- Northern Calcareous Alps and Silvretta Crystalline (Western Alps origin)

The gneisses, schists, and amphibolites of the Silvretta Crystalline of the Variscan age are the oldest rocks in the area. The Helvetic limestones and marls (as well as the NCA) were formed in a shallow sea in Mesozoic times, whereas the deep turbiditic origin of the Vorarlberg Flysch dates back to the Late Cretaceous-Early Tertiary Period. The Molasse was deposited instead in the Alpine foreland basin as a residual product of the mountain building process and consists of conglomerate sandstones, claystone and marls of mixed marine and non-marine nature [36].

In the Montafon valley (study area III) tectonic deformation and weakening of rock strength during Alpine orogenesis favors the occurrence of landslides [37]. Additionally, glacial erosion led to the steepening of slopes, triggering tensional fissures and accelerating a number of geomorphological processes, e.g., rock slides and rock falls [38].

In Bregenzerwald (study area IV), the valley slopes were oversteepened by glacial erosion, leading to increased slope instability after deglaciation [39]. In May 2005, intense and prolonged rainfall induced inundations and numerous landslides, leading to severe infrastructure and property damages. Prominent examples of major landslides in the Bregenzerwald area are the Doren landslide and the landslide Rindberg/Sibratsgfäll [40,41]. 


\subsubsection{Study Area V in Südtirol—Alto Adige Autonomous Province}

The major lithological formations of study area V (Südtirol-Alto Adige Autonomous Province; Figure 1) are [42]:

- Schiliar dolomites (detritic massive dolomite of Anisian age)

- Wengen formation (marls and calciturbidites mixed with volcaniclastic conglomerates of Ladinian age)

- $\quad$ S. Cassian formation (grey mudstones and calciturbidites of Carnian age)

The geology of the Dolomite area is complex being the result of the dismantling of the Hercinian mountains and Permo-Trias rifting tectonics in Permian times, which gave way to the Athesian magmatism [42]. In Anisian times, the massive detritic Schiliar dolomite was formed as a consequence of a rifting event. After another upper Ladinian paroxistic volcanic phase, the Wengen formation was formed. The successive recovery of carbonate sedimentation allowed the right conditions for the sedimentation of the S. Cassiano Formation [43].

The Gader Valley (study areas $\mathrm{V}(\mathrm{a})$ and $\mathrm{V}(\mathrm{b})$ ) is prone to gravitational processes such as landslides due to its geological and geomorphological conditions, particularly the upper parts of the valley [44]. In December 2012, after long and intensive rainfall, a large landslide destroyed several buildings and endangered critical infrastructure in Badia. Further large landslides are located near the village of Corvara. The Corvara landslide, which affects an area of more than $2.5 \mathrm{~km}^{2}$ and has an overall volume of more than 300 million $\mathrm{m}^{3}$ [45], repeatedly causes damages to infrastructure. The most recent landslide happened in April 2014 at the border between Corvara and Colfosco. Some areas on its western part were reactivated in August 2016.

\subsection{Data}

For each study area, selected subsets of optical satellite images with different properties from different sensors were used (Table 1). Digital elevation models (DEMs), and particularly the derived slope information, were used as supplementary data. The database for Montafon and Bregenzerwald was also complemented by a terrain roughness index (TRI) layer, computed as the sum of change in elevation between a grid cell and its eight neighboring grid cells [46]. For the study areas in Salzburg, a DEM derived from airborne laser scanning (ALS), which is freely available at a resampled resolution of $10 \mathrm{~m}$ from the geodata portal of Austria (www.geoland.at), was used. For the two study areas in Vorarlberg, an ALS-based DEM at $5 \mathrm{~m}$ spatial resolution provided by the federal government of Vorarlberg was available. The ALS campaigns over the Austrian Alps were conducted between 2006 and 2013 by the regional governments. In Südtirol-Alto Adige Autonomous Province, a DEM at $5 \mathrm{~m}$ resolution (acquired between 2004 and 2006) was provided by the Autonomous Province of Bolzano via their geodata portal (http://geoportal.buergernetz.bz.it/default.asp).

Table 1. Selected database for each study area.

\begin{tabular}{|c|c|c|c|c|c|c|}
\hline $\begin{array}{l}\text { Study } \\
\text { Area }\end{array}$ & $\begin{array}{c}\text { Size } \\
\left(\mathrm{km}^{2}\right)\end{array}$ & $\begin{array}{l}\text { Optical } \\
\text { Sensor }\end{array}$ & Acquisition Date & Spectral Resolution ${ }^{1}$ & Spatial Resolution (m) & $\begin{array}{l}\text { DEM Resolution } \\
(\mathrm{m})\end{array}$ \\
\hline & & & & $1 \times$ pan & 15 & \\
\hline I & 4.7 & Landsat 7 & 28 July 2002 & $\begin{array}{l}7 \times \text { multispectral (blue, green, red, nir, } \\
\text { swir- } 1 \text {, thermal, swir- } 2 \text { ) }\end{array}$ & 30 & 10 \\
\hline II & 2.8 & SPOT-5 & 10 September 2011 & $3 \times$ multispectral (green, red, nir) & 2.5 & 10 \\
\hline III & 1.4 & WorldView-2 & 29 August 2015 & $\begin{array}{c}1 \times \text { pan } \\
4 \times \text { multispectral (blue, green, red, nir) }\end{array}$ & $\begin{array}{c}0.5 \\
2\end{array}$ & 5 \\
\hline IV & 1.8 & WorldView-3 & 13 August 2015 & $\begin{array}{l}1 \times \text { pan } \\
4 \times \text { multispectral (blue, green, red, nir) }\end{array}$ & $\begin{array}{c}0.5 \\
2\end{array}$ & 5 \\
\hline $\mathrm{V}(\mathrm{b})$ & 1.2 & Sentinel-2 & 27 August 2016 & $\begin{array}{l}13 \times \text { multispectral (coastal aerosol, blue, } \\
\text { green, red, red edge } 1-3, \text { nir, red edge } 4, \\
\text { water vapour, swir cirrus, swir 1-2) }\end{array}$ & $\begin{array}{l}10 \text { (blue, green, red, nir) } \\
20 \text { (red edge } 1-4, \\
\text { swir 1-2) } \\
60 \text { (other) }\end{array}$ & 5 \\
\hline
\end{tabular}

${ }^{1}$ refers to the available panchromatic (pan) and multispectral bands for each dataset. 
The image selection process relied primarily on the availability of cloud-free data acquired in the summer season, possibly soon after a major landslide-triggering event or after the reactivation of landslide processes. Regarding DEM information, the supply of multi-temporal and post-event data was limited; the available data sets were therefore considered even if the acquisition date is not always consistent with the respective optical images. Pre-processing of the satellite images was implemented with ERDAS IMAGINE software (Hexagon Geospatial, Stockholm, Sweden) and included:

- Pansharpening if a panchromatic band was provided along with multispectral bands.

- Orthorectification supported by rational polynomial coefficients (RPCs) and/or ground control points (GCPs) to achieve sub-pixel geolocation accuracies.

\subsection{Object-Based Landslide Mapping}

For semi-automated landslide mapping, object-based approaches were developed and applied for each dataset and study area. Efforts were made to follow similar workflows; however, due to the different characteristics of the satellite images and study areas and because of the varying complexity and appearance of landslides, the transferability was limited. Thus, the classification rules were adapted for each test case. Moreover, two different but interchangeable software products, eCognition 9.2 (Trimble Geospatial, Sunnyvale, CA, USA) and InterIMAGE 1.43 (Pontifical Catholic University of Rio de Janeiro (PUC-Rio) and Brazilian National Institute for Space Research (INPE), Rio de Janeiro, Brazil), were used to develop the knowledge-based image analysis workflows. The two products are similar in their logic and functionality, meaning that a workflow implemented in eCognition can also be implemented in InterIMAGE and vice versa. Since the major objective of this study is the evaluation of OBIA mapping results in comparison to manual mapping results, rather than the development of sophisticated mapping routines, the implemented OBIA approaches were kept as simple as possible to produce acceptable results in a fast and efficient manner.

Table 2 shows the software that was used for mapping landslides in each study area, the segmentation method and the segmentation parameters that were used for creating image objects, and the main classification parameters for identifying landslide objects. Slightly different segmentation and classification parameters were used for mapping the two large landslides in study area V. Thus, the sub-areas $(\mathrm{V}(\mathrm{a})$, a landslide near the villages of Badia and La Villa, and $\mathrm{V}(\mathrm{b})$, a landslide near the village of Corvara) were treated separately during OBIA mapping. In general, the Normalized Difference Vegetation Index (NDVI) and the slope information were most useful for the detection of landslide bodies. For refining the classification, further parameters (e.g., brightness, length/width ratio, relation to neighboring objects, compactness, perimeter/area ratio) were used additionally or in combination with each other. Thresholds were selected based on (1) an exploratory analysis of image object properties (e.g., mean slope, mean NDVI) and (2) recommendations in the literature [17,31].

Table 2. Software, the segmentation method and parameters (SP-Scale Parameter, S-Shape criterion, C-Compactness criterion), and the main classification parameters used for object-based landslide mapping for each case study.

\begin{tabular}{|c|c|c|c|}
\hline Study Area & Software & Segmentation Method and Parameters & Main Classification Parameters \\
\hline I & $\begin{array}{c}\text { eCognition } 9.2 \\
\text { (Trimble Geospatial) }\end{array}$ & Multiresolution segmentation: SP: 25; S: 0.1; C: 0.5 & $\begin{array}{c}\text { Mean diff. to neighbors (NDVI) }<0 \\
\text { Mean slope }>10 \\
\text { Length } / \text { Width }>4\end{array}$ \\
\hline II & $\begin{array}{c}\text { eCognition } 9.2 \\
\text { (Trimble Geospatial) }\end{array}$ & Multiresolution segmentation: SP: 15; S: 0.3; C: 0.5 & $\begin{array}{c}\text { Mean NDVI }<0.04 \\
\text { Mean slope }>10 \\
\text { Mean brightness }>85\end{array}$ \\
\hline III & InterIMAGE 1.43 & $\begin{array}{l}\text { Threshold segmentations based on NDVI and } \\
\text { brightness layer (Threshold = Mean of layer) }\end{array}$ & $\begin{array}{c}\text { Mean slope }>35^{\circ} \\
\text { Mean TRI }>1.5 \\
\text { Size }>100 \mathrm{~m}^{2} \\
\text { Perimeter } / \text { Area Ratio }(\mathrm{P} / \mathrm{A})<0.55 \\
\text { Mean NDVI }<0.55\end{array}$ \\
\hline
\end{tabular}


Table 2. Cont.

\begin{tabular}{|c|c|c|c|}
\hline Study Area & Software & Segmentation Method and Parameters & Main Classification Parameters \\
\hline IV & InterIMAGE 1.43 & $\begin{array}{l}\text { 1. Threshold segmentations based on NDVI and } \\
\text { brightness layer (Threshold = Mean of layer) } \\
\text { 2. Multiresolution segmentation based on slope; } \\
\text { SP: } 400 \text {; S: } 0.5 \text {; C: } 0.5\end{array}$ & $\begin{array}{l}\text { Same as III, except: } \\
\text { Mean slope }>15^{\circ} \\
\text { No use of Mean NDVI }\end{array}$ \\
\hline $\mathrm{V}(\mathrm{a})$ & $\begin{array}{c}\text { eCognition } 9.2 \\
\text { (Trimble Geospatial) }\end{array}$ & Multiresolution segmentation: SP: 150; S: 0.5; C: 0.5 & $\begin{array}{c}\text { Mean NDVI }<0.4 \text { or }<0.5 \text { (depending on fine } \\
\text { adjustment in combination with other features) } \\
\text { Mean slope }>10\end{array}$ \\
\hline $\mathrm{V}(\mathrm{b})$ & $\begin{array}{c}\text { eCognition } 9.2 \\
\text { (Trimble Geospatial) }\end{array}$ & Multiresolution segmentation: SP: 150; S: $0.3 ;$ C: 0.8 & $\begin{array}{c}\text { Mean NDVI }<0.4 \\
\text { Mean slope }>8 \\
\text { Length } / \text { Width }>1.6 \\
\text { Shape index }<3.6\end{array}$ \\
\hline
\end{tabular}

\subsection{Manual Landslide Mapping}

Three different types of features were manually mapped. First, points at the central area of landslide scars were located. Second, the same DEMs as for semi-automated mapping were used to recognize and digitize the crown scars (if possible) and at last, for most of the mass movements detected, polygons were drawn. Some basic information was recorded and stored in a GIS database assigned with several attribute fields covering the following aspects:

- Technical aspects connected to the intrinsic characteristics of the sensors adopted (Table 3)

- Geomorphologic and physical aspects of the phenomena mapped (Table 4)

- Statistical information showing, for example, the number of mapped landslides and their size (Table 5)

Table 3. Database fields that describe how the remote sensing image quality influences the manual landslide mapping.

\begin{tabular}{ccccc}
\hline Band Combination & Digitalization Level of Detail & Geometric Quality & Completeness Quality & Landslide Classification Quality \\
\hline \multirow{3}{*}{ R-G-B } & Mapping Scale (varies between & accurate (1) & complete (1) & certain (1) \\
\cline { 3 - 5 } & $\begin{array}{c}\text { low degree of } \\
\text { inaccuracy (2) }\end{array}$ & $\begin{array}{c}\text { high degree of } \\
\text { completeness (2) }\end{array}$ & low degree of uncertainty (2) \\
\cline { 3 - 6 } & spatial resolution & $\begin{array}{c}\text { high degree of } \\
\text { inaccuracy (3) }\end{array}$ & $\begin{array}{c}\text { low degree of } \\
\text { completeness (3) }\end{array}$ & high degree of uncertainty (3) \\
\cline { 3 - 6 } & & inaccurate (4) & incomplete (4) & uncertain (4) \\
\hline
\end{tabular}

The technical aspects concerning the scale used for the manual mapping can be distinguished between objective and subjective ones. The first group contains aspects such as the band combination (most of the time false color composite infrared was used) and the spatial resolution, which influenced the digitalization scale. For the second group, a broader distinction was proposed; for subjective factors, which are synthesized in three quality fields (Table 3), scores from 1 (best) to 4 (worst) were assigned to each polygon created.

The first quality field is related to the geometry that relies directly on the image resolution; for example, landslides mapped on Landsat 7 result in a lower geometric accuracy than landslides mapped on SPOT-5 and WorldView-2/3 images. The completeness quality field represents a purely subjective index, being related to the ability of the operator to map a phenomenon as completely as possible. In this case, the landscape context and local characteristics such as forest presence, which obliterated parts of the phenomena, or the re-growing of vegetation, which concealed previous landslide scars and deposits, played a very important role. Concerning the landslide classification quality, the best score was reached when a VHR image was available for the manual mapping.

Visual interpretation partly allowed distinguishing between different subtypes and parts of landslides (Table 4), depending on the specific geographical and geological settings of the five study areas. If a landslide scar could be identified, then it was represented as polyline; when the scar 
could not be recognized due to data constraints, the accumulation and the transport areas were mapped instead.

The presence of a DEM in order to delineate the exact boundaries of the landslides was useful; even if it was mainly used for the confirmation of the scar extension highlighted in the VHR images (by means of the hillshade and the contour lines). Bulges identification on the deposition area were also supported by the digital elevation data, whereas, since the trail left at the transport section of a landslide is enhanced by a difference in local re-growing of vegetation, only the optical images could be used for identifying these landslide sub-parts.

The landslide activity field was derived from additional alternative data sources (e.g., a public image Web Map Service (WMS) showing older aerial photography for the study areas I, II, and V), published landslide data such as the multi-temporal landslide inventory of Vorarlberg [47] for study areas III and IV, and from unpublished material such as the Austrian mass movement cadastre GEORIOS [48] for study area II, since it was not possible to obtain this information from satellite imagery from one point in time. Objects stored in the GEORIOS database were digitized from geological maps published at different scales (ranging between 1:50,000 and 1:5,000). Although this information represents historical evidence of mass movements, these kind of products only represent active (at the time of the map release) phenomena that are larger than the surrounding geological feature [49] and care should be taken when using this information in order to produce detailed (scale 1:10,000) landslide inventories.

Table 4. Database fields that describe the geomorphological aspects of the manually digitized landslides.

\begin{tabular}{ccccc}
\hline Landslide Type & Landslide Subtype & Landslide Accumulation & Landslide Transport & Landslide Activity ${ }^{1}$ \\
\hline $\begin{array}{c}\text { Landslide process } \\
\text { type classification }\end{array}$ & Landslide process & accumulation area complete (1) & transport area complete (1) & active (1) \\
i50] & incomplete (2) & probably still active (2) \\
abse classification & abo,51] & absent (3) & dormant (3) & not active (4) \\
\hline
\end{tabular}

${ }^{1}$ based on additional archived data and literature.

\subsection{Comparison Methods}

For comparing the semi-automated mapping results from OBIA to the mapping results of the visual landslide interpretation, the traditional thematic accuracy assessment approach for land use/land cover image classifications has been employed and adapted [52-54]. It has been applied for landslide classifications by Hölbling et al. [23]. Accordingly, we calculated the landslide area that was mapped by both methods (i.e., the overlapping area). Based on this overlapping area, the respective producer's (overlap expressed as share of the manual mapping area) and user's (as share of the OBIA mapping area) accuracies were computed. Furthermore, the difference in the landslide area mapped by both methods was computed and expressed as a ratio relative to the manual mapping area.

Beyond the area-based comparison, we performed a comparison of the number of polygons mapped as landslides. The difference in the count of landslide polygons between the OBIA result and the manual mapping result was expressed as a ratio relative to the manual mapping count.

Additionally, a set of object-by-object comparison metrics was calculated, which has proven to be useful in the geomorphological context of object-based landform delimitation [55]. Spatial accuracy metrics were used to quantify the spatial match between the manually digitized landslide polygons (considered reference areas) and the landslide polygons extracted with OBIA workflows (considered test areas). In total, five established spatial accuracy metrics were selected [55-57]: (1) Quality Rate (QR), (2) Area-Fit-Index (AFI), (3) Over-Segmentation Rate (OR), (4) Under-Segmentation Rate (UR), and (5) a compound metric D, which combines OR and UR. All these metrics rely on area proportions, i.e., the area of manual polygons, the area of OBIA polygons, and the spatial overlap between manual and OBIA polygons. Except for AFI, the possible range of values is from 0 to 1 . A value of 0 indicates a perfect spatial match between the manual and the OBIA area, i.e., the areas have exactly the same 
spatial extent. In contrast, if the manual and OBIA polygons do not produce any spatial overlap, a value of 1 is obtained. A value around 0.5 can be interpreted such that the majority of manual polygons are overlapped by OBIA polygons but that the spatial extent of the overlapping polygons is different and that some non-overlapping polygons exist. Only the values of AFI can be negative. For the presented landslide mapping tests, it is therefore desirable to obtain metric values as close as possible to 0 . The computation of the metrics was automated in the open source software QGIS (Open Source Geospatial Foundation, Beaverton, OR, USA), based on a tool that has been developed previously for use in object-based software [55]. Metrics were computed (1) globally, i.e., for all landslides per study site, and (2) locally, i.e., separately for each landslide. The formulas for and mathematical notations of the spatial accuracy metrics can be found in Clinton et al. [56]. It is also important to mention that there exists a mathematical relation between UA and UR, as well as PA and OR; the total (not percentage) values of each pair (UA-UR, PA-OR) sum up to 1.

Next to the calculation of spatial accuracy metrics, a non-spatial accuracy metric, the so-called Miss Rate (MR), was used. MR quantifies the completeness of the semi-automated landslide extraction process. It is computed as the ratio between the number of undetected manual polygons and the total number of manual polygons per study site [55]. The range of values is between 0 and 1 . The closer the values are to 0 , the more complete is the OBIA landslide extraction.

\section{Results}

\subsection{Landslide Mapping Results}

\subsubsection{OBIA Landslide Mapping Results}

Figures 2-6 show the OBIA landslide mapping results in comparison to the manual mapping results for each study area. There is good coincidence between most of the results; however, several disparities can be observed that are often related to the ability of a human interpreter to delineate a landslide body as whole, even if parts of the landslide are covered by vegetation. This is the case, for example, for the large landslide near the villages of Badia and La Villa in Südtirol-Alto Adige Autonomous Province (study area V(a)). Similarly, landslides that are still visible on the images but are already overgrown by grass are difficult to detect semi-automatically due to the missing spectral difference to the surrounding areas. This can be recognized in the southwestern part of study area IV, where not all landslides, and particularly landslide tails, could be detected. The detection of landslides by OBIA was most challenging in study area II, since it was hardly possible to differentiate landslides from other processes using the SPOT-5 image and the DEM only. Statistics and detailed information about the accuracy of the semi-automated mapping in comparison to the manual mapping are given in Section 3.2.
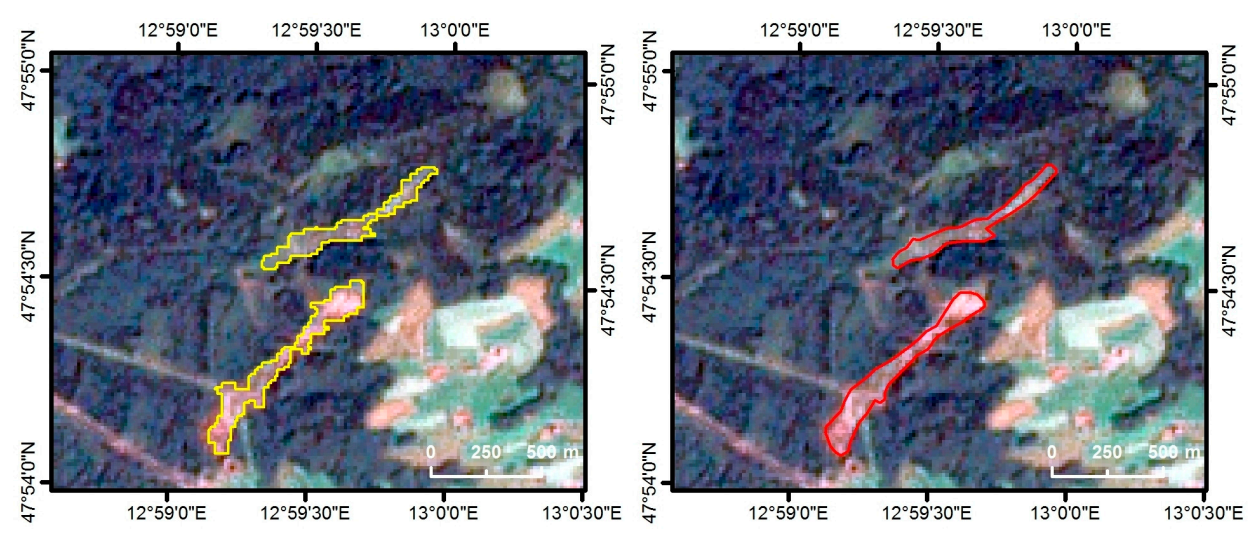

Figure 2. Semi-automatically mapped landslides using the object-based image analysis (OBIA) approach (in yellow; left) and manually mapped landslides (in red; right) for study area I based on the Landsat 7 image. 

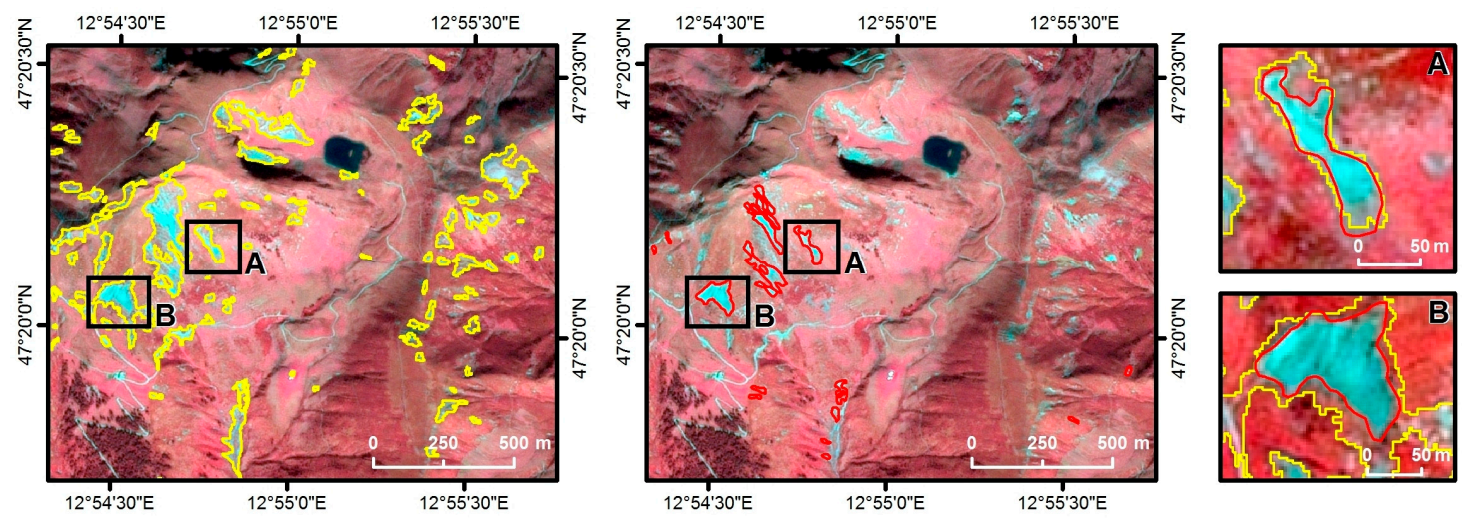

Figure 3. Semi-automatically mapped landslides using the object-based image analysis (OBIA) approach (in yellow; left) and manually mapped landslides (in red; middle) for study area II based on the SPOT-5 image. Two subsets demonstrating the variation of the mapping results for selected landslides are shown on the right. The black rectangles (A, B) indicate the location of the subsets.
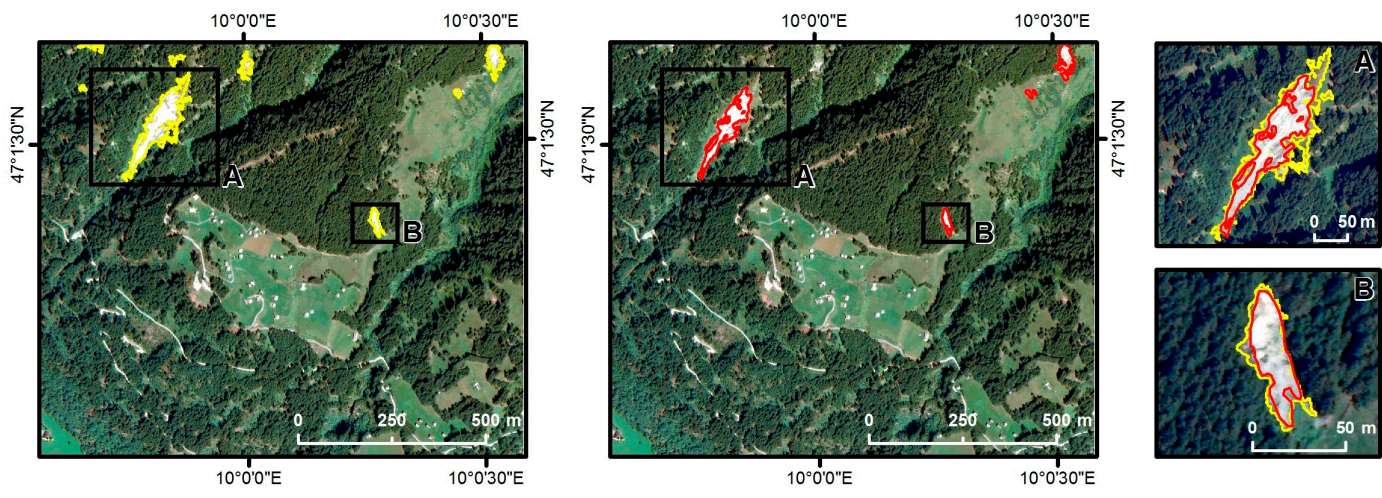

Figure 4. Semi-automatically mapped landslides using the object-based image analysis (OBIA) approach (in yellow; left) and manually mapped landslides (in red; middle) for study area III based on the WorldView-2 image. Two subsets demonstrating the variation of the mapping results for selected landslides are shown on the right. The black rectangles (A, B) indicate the location of the subsets.
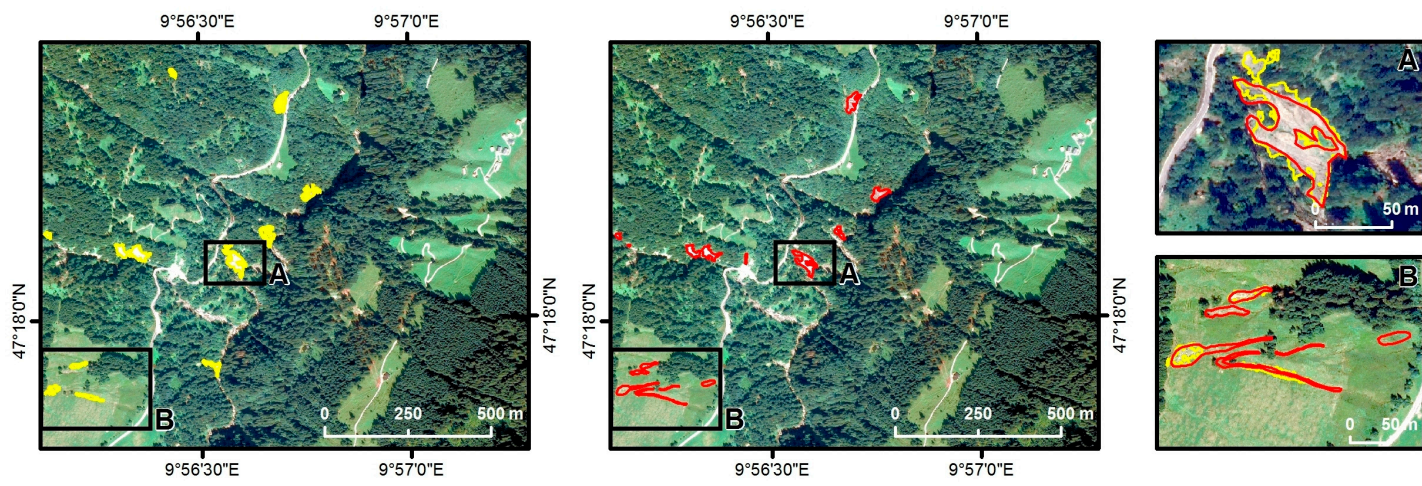

Figure 5. Semi-automatically mapped landslides using the object-based image analysis (OBIA) approach (in yellow; left) and manually mapped landslides (in red; middle) for study area IV based on the WorldView-3 image. Two subsets demonstrating the variation of the mapping results for selected landslides are shown on the right. The black rectangles (A, B) indicate the location of the subsets. 

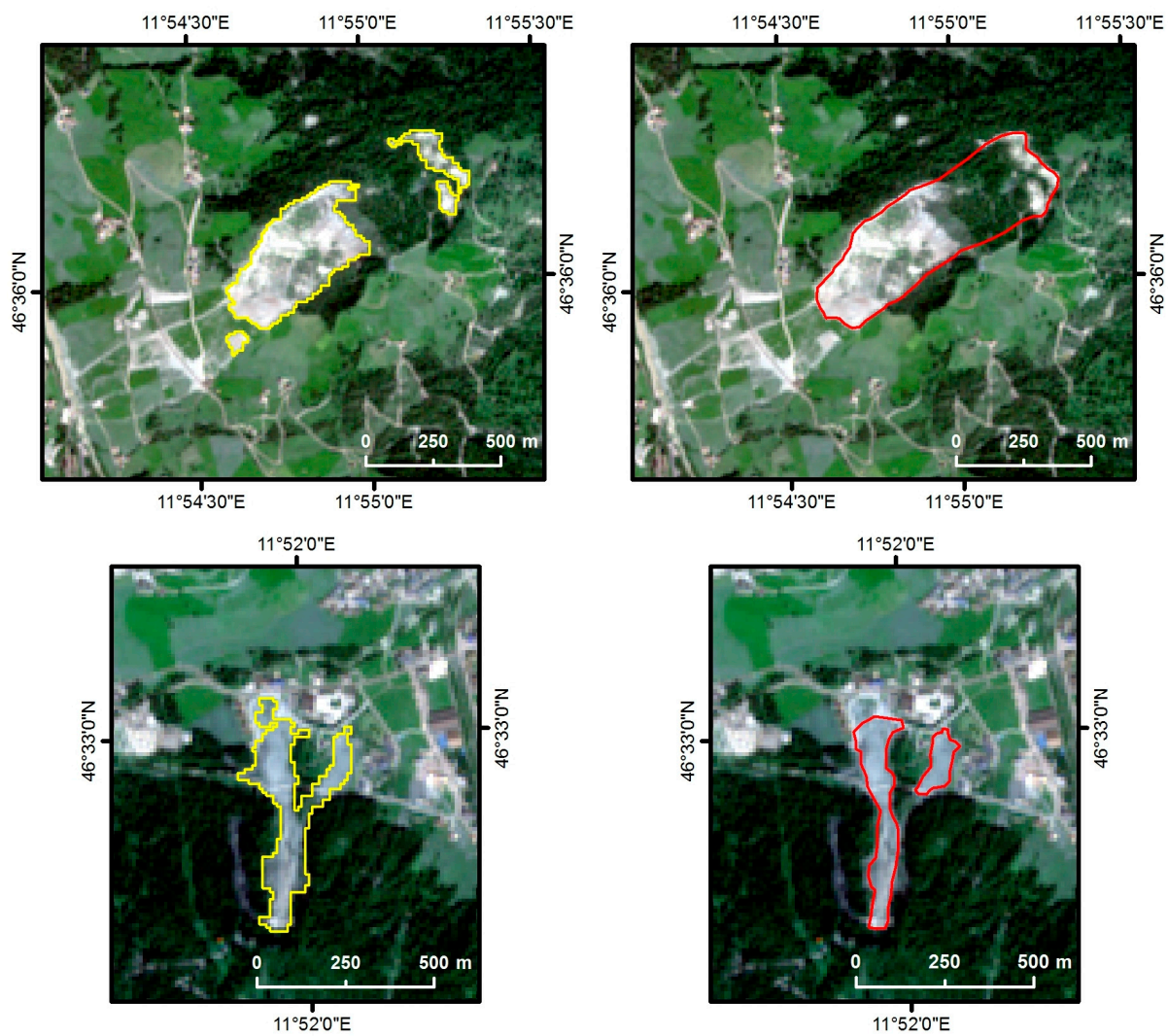

Figure 6. Semi-automatically mapped landslides using the object-based image analysis (OBIA) approach (in yellow; left) and manually mapped landslides (in red; right) for study areas V(a) (top) and $\mathrm{V}(\mathrm{b})$ (below) based on the Sentinel-2 image.

Table 5 presents some basic statistics for the OBIA mapping results for each study area.

Table 5. Statistics of the OBIA mapping results for each of the five study areas.

\begin{tabular}{cccccc}
\hline Statistical Property & Study Area I & Study Area II & Study Area III & Study Area IV & Study Area V \\
\hline Number of landslides & 2 & 85 & 9 & 11 & 5 \\
Area affected by landslides $\left(\mathrm{km}^{2}\right)$ & 0.148 & 0.203 & 0.019 & 0.011 & 0.250 \\
Smallest mapped landslide $\left(\mathrm{m}^{2}\right)$ & 59700 & 75 & 135 & 244 & 4200 \\
Largest mapped landslide $\left(\mathrm{m}^{2}\right)$ & 87900 & 38741 & 12577 & 2400 & 148800 \\
Average size of mapped & 73800 & 2393 & 2110 & 992 & 49960 \\
landslides $\left(\mathrm{m}^{2}\right)$ & & & & \\
\hline
\end{tabular}

\subsubsection{Manual Landslide Mapping Results}

Table 6 shows the statistics of the manual landslide mapping results for each study area. Probably the most notable case is the Pinzgau study area (II). This is a special area of interest, being a mountainous area characterized by a high relief and sparse vegetation, where several geomorphological phenomena such as snow scars induced by avalanches, gully erosions connected to torrent activity, and rock glacier deposits could be perceived and mapped as mass movements. Surprisingly, a high landslide density can be recognized. Since the differentiation of landslides from other mass movement types only based on the SPOT- 5 image and the $10 \mathrm{~m}$ DEM was hardly possible in this case, even by visual interpretation, a $5 \mathrm{~m}$ DEM and aerial photography from 2011 (accessible through a free WMS service) were additionally used for manual landslide mapping. Furthermore, some GEORIOS polygons were used as guidance for the identification of landslide subtypes. 
Table 6. Statistics of the manual mapping results for each of the five study areas.

\begin{tabular}{cccccc}
\hline Statistical Property & Study Area I & Study Area II & Study Area III & Study Area IV & Study Area V \\
\hline Number of landslides & 2 & 18 & 5 & 14 & 3 \\
Area affected by landslides $\left(\mathrm{km}^{2}\right)$ & 0.140 & 0.031 & 0.011 & 0.010 & 0.320 \\
Smallest mapped landslide $\left(\mathrm{m}^{2}\right)$ & 54855 & 247 & 66 & 10781 & 270 \\
Largest mapped landslide $\left(\mathrm{m}^{2}\right)$ & 85339 & 8374 & 7200 & 1882 & 709 \\
Average size of mapped landslides $\left(\mathrm{m}^{2}\right)$ & 70097 & 1830 & 2157 & 106533 \\
\hline
\end{tabular}

The three quality fields were introduced in order to trace back the logic used for the task of manual landslide mapping and to communicate the perceived difficulties encountered during the mapping process. The three quality indices are directly correlated to the spatial resolution of the used satellite images. For each of the analyzed images, the achievable score varies. The best score reached among all the quality categories is:

- Score of "1" for study area III and IV (1 $\mathrm{m}$ resolution)

- Score of " 2 " for area II ( $2.5 \mathrm{~m}$ resolution) and area V (10 m resolution)

- Score of " 3 " for study area I (15 m resolution)

In general, when considering all quality measures, the best results were achieved on the VHR images (including area II with $2.5 \mathrm{~m}$ resolution), always bearing in mind the subjectivity introduced by the interpreter.

\subsection{Accuracy Assessment}

A variety of different metrics was used to quantitatively capture the agreement between the OBIA mapping results and the manual delineation. Comparisons were performed in all study areas and for all datasets.

\subsubsection{Comparison of Overlapping Areas}

The metrics according to the general accuracy assessment approach for image classifications, as presented in Hölbling et al. [23], are summarized in Table 7. Concerning the number of landslides, the best agreement occurred in study area I (Fürwag), where both approaches detected two large landslides. The highest discrepancy occurred in study area II (Pinzgau), where a large number of objects were considered landslides only by the OBIA result but not by the manual delineation. In the other study areas, the OBIA and manual results deviated from each other by two to four landslides. Since the numbers of landslides were relatively low, with a count between three and 14, the difference by percentage still showed high values between $-20 \%$ and $80 \%$. The comparison of the landslide affected area reveals similar tendencies: again, study area I showed the best agreement with a difference of only $5.28 \%$, and study area II showed the highest discrepancy, with OBIA detecting an affected area that is almost five times as large as the manual mapping. In study area III (Montafon), the difference in the landslide-affected area was $76 \%$ and reflected the agreement already shown by the difference in landslide numbers. For study area IV (Bregenzerwald) and study area V (Gader Valley), the OBIA deviation from the manually mapped area is relatively low, with $9.91 \%$ and $-21.8 \%$., but here the difference shows a contrasting direction related to the number of landslides. The producer's and user's accuracy values in study area I and IV were very similar. For study area II, the values show that most of the landslide affected areas identified with manual mapping have also been captured by OBIA (producer's accuracy 90.6\%) but that many more areas were classified that were left out by manual mapping (user's accuracy 15.6\%). Study areas III and V(b) show a similar situation to study area II but not as pronounced. Study area $\mathrm{V}(\mathrm{a})$ showed the opposite behavior because a significant portion of a landslide has been included in the manual mapping that was not covered by the OBIA result. 
Table 7. Comparison of OBIA mapping results and manual mapping results per study area.

\begin{tabular}{|c|c|c|c|c|c|}
\hline Comparison Metric & Study Area I & Study Area II & Study Area III & Study Area IV & Study Area V \\
\hline Number of landslides (OBIA) & 2 & 85 & 9 & 11 & 5 \\
\hline Number of landslides (manual) & 2 & 18 & 5 & 14 & 3 \\
\hline Difference in numbers OBIA—manual (count; \%) & $\begin{array}{c}0 \\
0 \%\end{array}$ & $\begin{array}{c}+67 \\
372 \%\end{array}$ & $\begin{array}{c}+4 \\
80 \%\end{array}$ & $\begin{array}{c}-3 \\
-21 \%\end{array}$ & $\begin{array}{c}+2 \\
+67 \%\end{array}$ \\
\hline Landslide affected area (OBIA, km²) & 0.148 & 0.203 & 0.0190 & 0.0109 & 0.250 \\
\hline Landslide affected area (manual, $\mathrm{km}^{2}$ ) & 0.140 & 0.0351 & 0.0108 & 0.00993 & 0.320 \\
\hline Area difference OBIA-manual (\%) & $5.28 \%$ & $480 \%$ & $76 \%$ & $9.91 \%$ & $-21.8 \%$ \\
\hline Overlap area $\left(\mathrm{km}^{2}\right)$ & 0.118 & 0.0318 & 0.0104 & 0.00691 & 0.208 \\
\hline Producer's Accuracy (\%) & $84.3 \%$ & $90.6 \%$ & $95.8 \%$ & $69.6 \%$ & $\begin{array}{l}V(a): 60.6 \% \\
V(b): 90.0 \%\end{array}$ \\
\hline User's Accuracy (\%) & $80.1 \%$ & $15.6 \%$ & $54.4 \%$ & $63.3 \%$ & $\begin{array}{l}V(a): 91.2 \% \\
V(b): 62.7 \%\end{array}$ \\
\hline
\end{tabular}

\subsubsection{Completeness of the Semi-Automated Extraction}

Relatively low MR values in the range from 0 to 0.35 were obtained (Figure 7), demonstrating that at least two thirds of the manual polygons were also extracted by the OBIA method. For the Gader Valley and Fürwag, even all reference polygons were detected with the semi-automated workflows. This is indicated by a MR value of 0 . However, for these areas, the total number of reference polygons was small $(n=1-2)$ and the spatial extent relatively large. Usually, the combination of low reference number and large reference areas increases the success of the automated landslide detection, which is also supported by the presented results.

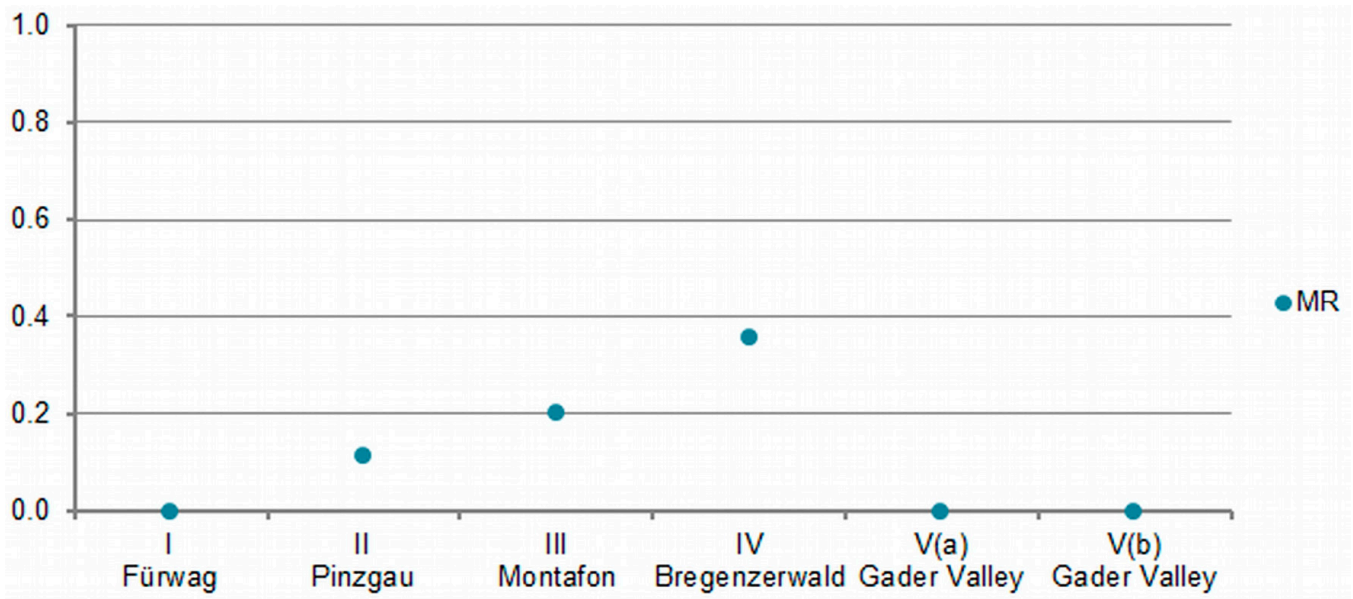

Figure 7. Completeness of the automated landslide extraction, quantified by the values of Miss Rate (MR).

\subsubsection{Spatial Accuracy of the Semi-Automated Extraction}

Generally, global spatial accuracy values are below 0.5 , indicating good to high spatial agreements between the reference and automated landslide polygons for the selected study sites (Figure 8). Only for the Pinzgau area higher values, and hence, lower spatial accuracies were achieved. For Pinzgau, the high values of $Q R, D$, and UR show that there is a high difference between the size of reference and test polygons. As a result, small spatial overlaps are produced. Since OR is close to 0 and AFI is negative (Figures 8 and 9), it can be concluded that the extracted landslide polygons are far larger than the reference polygons and/or that landslides were extracted at the wrong locations, i.e., the automated extraction over-estimates the spatial extent of the reference. To a lesser extent, the afore-mentioned conclusion also holds true for the Montafon study site (III). From Figures 8 and 9, it is also obvious that study area $\mathrm{V}(\mathrm{a})$ is the only area where the value of UR is lower than OR and where AFI is positive. This means that the extracted landslide polygon is smaller than the reference polygon $(n=1)$, 
i.e., the extraction under-estimates the reference. The best spatial agreement between reference and test polygons was obtained for the Fürwag area $(n=2)$. The spatial accuracy values are relatively low, and the deviation between them is minimal. These characteristics are achieved if the over- and under-estimated areas are relatively small and the area proportions of the overlap, test, and reference polygons are similar.

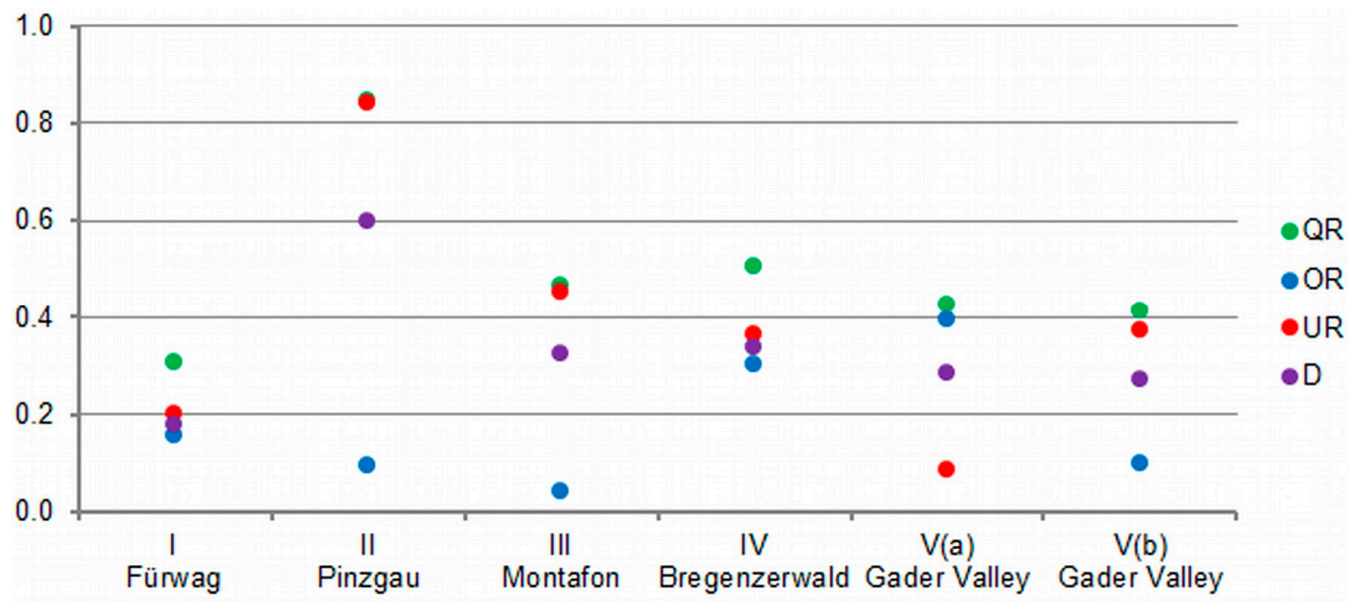

Figure 8. Global spatial accuracies for the selected study sites. Results presented for four metrics; Quality Rate (QR), Under-Segmentation Rate (UR), Over-Segmentation Rate (OR), and the UR-OR compound metric D.

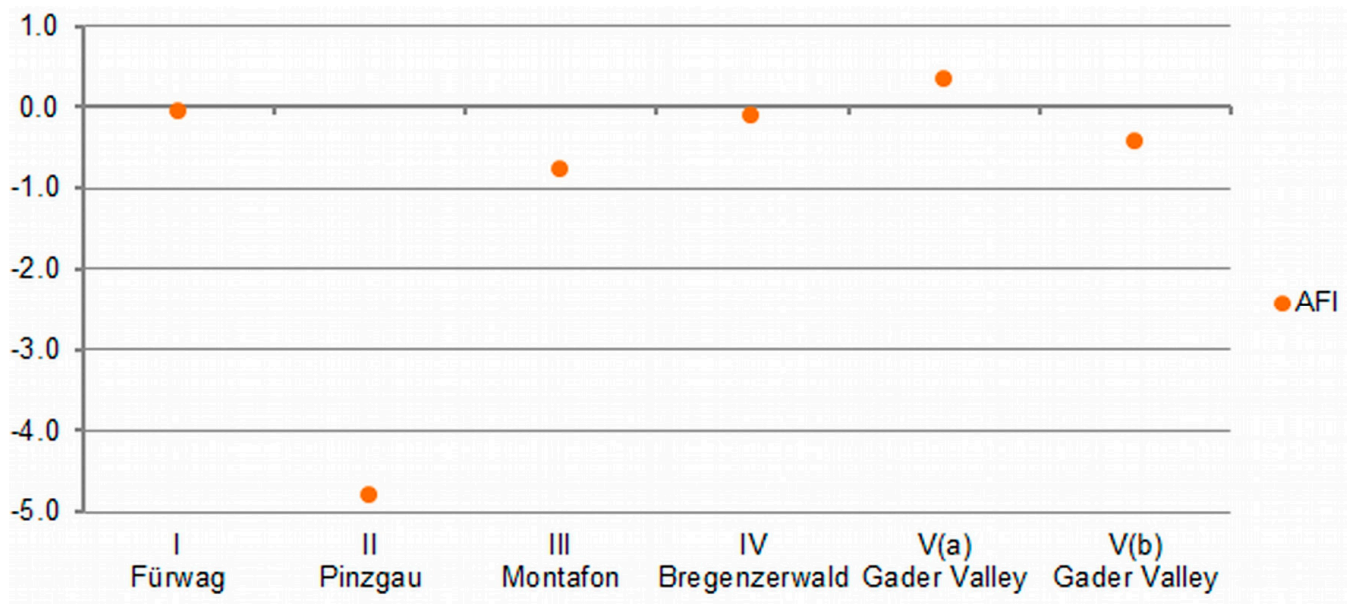

Figure 9. Global values of Area-Fit-Index (AFI) for the selected study sites.

Figure 10 depicts the spatial accuracy signatures of individual landslides per study site. The signatures are obtained by plotting the four metrics, QR, UR, OR, and D; each on one side of the X-and Y-axis. In case of high spatial agreement, the shape of the graph is diamond-like and the diamond is positioned as close as possible around the zero point. The afore-mentioned characteristics are best met for the two Fürwag landslides. When looking at the deviation of spatial accuracy signatures for the landslides per study area, it can be concluded that the lowest values are obtained for Fürwag and Montafon, whereas for Pinzgau and Bregenzerwald higher deviations are depicted in Figure 10. Higher deviations indicate a higher variation of results for a study area, i.e., some reference landslides are under-estimated by the test polygons, while others are over-estimated. 


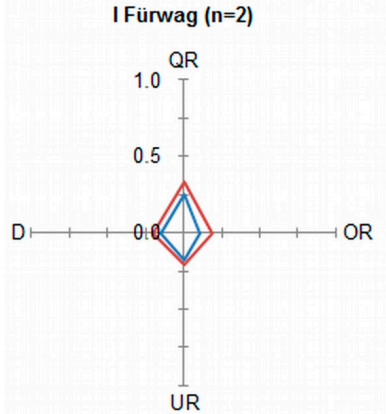

UR

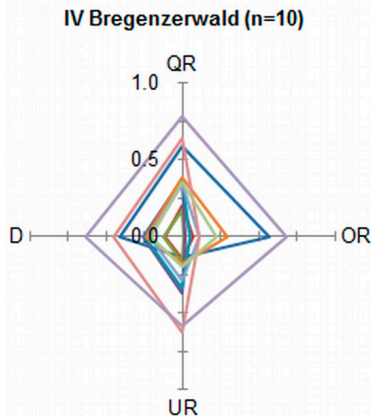

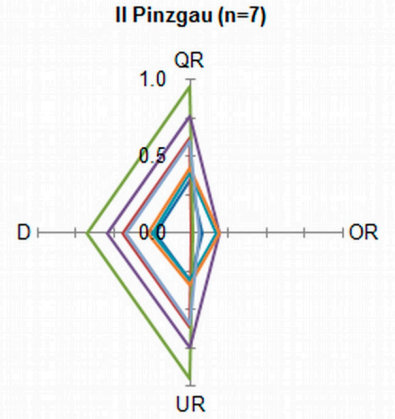

UR

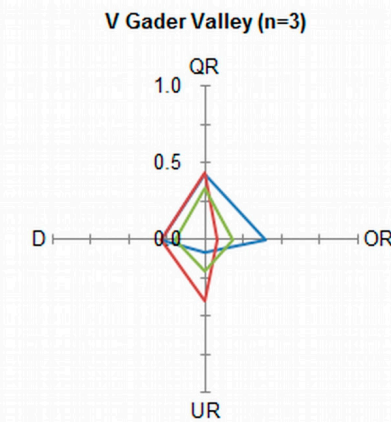

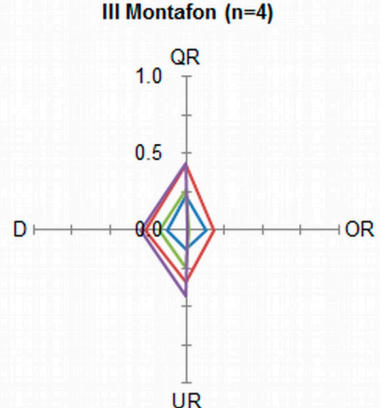

UR

Figure 10. Landslide-specific spatial accuracy values per study site I-V. Each graph in I-V depicts the spatial accuracy signature of a detected landslide. Results presented for four metrics; Quality Rate (QR), Under-Segmentation Rate (UR), Over-Segmentation Rate (OR), and the UR-OR compound metric D.

\section{Discussion}

Landslide maps produced with semi-automated methods are commonly compared to manually mapped landslides in order to quantitatively assess the accuracy of results. Visual interpretation, however, while still the most common method for mapping landslides on optical remote sensing data, has some disadvantages: it is a time-consuming process, depends on various factors, and cannot constitute a completely "true" reference. However, often it is the only available reference data $[8,23]$. A "true" reference, i.e., ground truth reference data, would require the reference dataset to be of a significantly higher accuracy and to be collected independently from the tested dataset [58]. The manual delineation and the OBIA mapping are two independently performed processes, but they employ the same satellite images, and thus their results cannot be considered fully independent. For the same reason, the manual interpretation did not result in landslide delineation with a significantly higher accuracy. Consequently, manual mapping implies some degree of uncertainty that cannot be avoided, even if created by an expert. Therefore, if some of the disagreement between the two compared datasets can be attributed to the uncertainty in the manual delineation, the accuracy of the OBIA results may be larger than the calculated accuracy values suggest. At least they would fall in the same range of acceptable uncertainty that commonly used manual delineations imply. Of course, this could only be confirmed if a valid ground truth reference dataset was available that also allows the accuracy of the manual delineation to be assessed. In the current practice of assessing the accuracy of OBIA results with manual delineations, only strong disagreements can clearly be attributed to mapping errors, e.g., in the case of study area II where a user's accuracy value of only $15.6 \%$ occurred. The conceptual problem remains that the manual mapping does not completely fulfill the standards as a reference for a classical accuracy assessment. Due to the uncertainty inherent in the manual mapping, we suggest to use the term "agreement" instead of "accuracy" when comparing the two classifications. The concept of agreement for evaluating the quality of OBIA landslide mapping results also applies to other fields of applications where a fully reliable reference is missing. The approach of assessing the agreement may not yield as sharp a quality indicator as the classical approach of an accuracy assessment, but it can still be highly valuable. The selection of appropriate quality indicators is a 
subject for a necessary discussion within the landslide community. It enables the design of a validation approach for EO-based landslide mapping that conforms to the Quality Assurance Framework for Earth Observation (QA4EO; http:/ QQA4EO.org/).

The accuracy assessment achieved a number of different metrics that were used for assessing the accuracy of the OBIA landslide maps. In addition to classical PA and UA, which were computed separately for each site, this study proposes to integrate spatial accuracy metrics for quantifying the spatial agreement between manual and automated landslide polygons on an object-by-object basis. The use of landslide-specific accuracies allows a more detailed interpretation of the results. For instance, the deviation of landslide accuracy values within a study area may give clues about the stability/robustness of the automated extraction workflow. The best results where all measures show similar values were achieved for study area I, with PA and UA of approximately $80 \%$ and QR, UR, $\mathrm{OR}$, and D of approximately 0.2. However, for area I only two reference polygons were extracted. The results of this study confirm that lower accuracies are achieved for areas where a larger number of landslides have to be mapped by OBIA methods. We also compared delineations of single landslides that performed equally well or even better. However, what makes it difficult to interpret the calculated accuracy values is the lack of information about the accuracy thresholds accepted within the landslide community. Such information would be highly valuable for estimating the quality of landslide maps derived from EO data with semi-automated methods.

The results in this study obviously show that the very high spatial resolution of the optical satellite image does not necessarily guarantee a high quality of the automated landslide mapping. The relative quality of semi-automated landslide mapping can be better for Landsat 7 data than for WorldView-2/3 images, as exemplified by the Fürwag test case. However, when drawing such conclusions, one has to keep in mind that there is a direct relationship between the spatial resolution of the optical satellite image and the reliability of the reference polygons digitized therefrom. It is not surprising that VHR images allow the mapping of smaller landslides and to some degree also the differentiation of subtypes, particularly during manual mapping. On the other hand, Landsat 7 and Sentinel-2 proved their applicability for identifying and delineating larger landslides, whereby the agreement between both results was high (apart from the special case of study area V(a), as described below). Especially Sentinel-2 can be considered a relevant data source for semi-automated landslide mapping and landslide change detection, also because of its high revisiting frequency.

Both methods produced acceptable and comparable results. However, the differentiation of landslide types and sub-parts with OBIA was not possible with the available data. Very high resolution DEM data from different dates would be helpful for that, but data availability was limited. Also, optical data acquired directly after a landslide triggering event and another image taken several weeks or months later could be helpful for the semi-automated differentiation of source, transport, and accumulation area, since landslide tails tend to revegetate faster than landslide scars [23]. These difficulties become obvious when looking at the results from the Pinzgau study area, where different mass movement processes are present. While the OBIA approach classified too many areas as landslides due to similar spectral properties, only a few landslides were identified by manual mapping. In such a case, ground truthing would be necessary to create a reliable landslide inventory. An example that requires expert interpretation can be found in the southwestern part of the Bregenzerwald study site where some small shallow landslides were manually mapped, which could not be identified by OBIA despite the use of WorldView-3 since they were already grassed over. Study area $\mathrm{V}(\mathrm{a})$ is an interesting case because a significant portion of a landslide has been included in the manual mapping that was not covered by the OBIA mapping. This part of the landslide is covered by vegetation. In the manual interpretation, the inclusion of this part was logically inferred by expert knowledge, an element that is difficult to implement in automated mapping workflows. Eisank et al. [31] proposed a knowledge-based landslide mapping system, but further research is needed in this direction to compete with a human interpreter. 
Two OBIA software products with a different range of functionalities were used for semi-automated landslide mapping, both delivering acceptable results for the presented case studies. OBIA workflows were developed in such a way that they can potentially be set up in any of the two software products, but each image analysis tool consists of different implemented approaches for image segmentation and classification. As a consequence, the workflows may produce different results, particularly related to the object delineations. Further studies could focus on a systematic comparison of the applicability of different software products to identify the most adequate tool for each sensor and landscape characteristic. However, this also depends on the data used and on the preferences and skills of the software user.

By combining both approaches, i.e., starting with the semi-automated detection of landslide candidates and then refining this classification manually, the whole mapping process could be improved while achieving adequate mapping results. Particularly large-scale mapping tasks would probably benefit from a degree of automation [59]. By implementing such a combined approach in an interactive and easy-to-use web service intended for practitioners with at least a certain knowledge in landslide recognition, landslide mapping could become faster and more efficient $[60,61]$. Such a web service can be relevant, especially for users and practitioners who might not be familiar with sophisticated image analysis software.

\section{Conclusions}

In this study we compared two landslide mapping approaches, OBIA and manual mapping, in five selected test areas with various geological and geomorphological settings in the Alps. Satellite images with different resolutions from different sensors were used. The analyses show that both methods produce similar results, whereby the achieved accuracy values vary between the study areas. It is important to note that using manual mapping for reference is critical, and the associated uncertainty should be considered when interpreting the accuracy values. While visual expert interpretation has advantages for differentiating landslides subtypes and for delineating single landslides as single objects and thus to identify the number of mapped landslides, it is a subjective and time-consuming task. This subjectivity issue is difficult to measure but influences the reliability of the landslide mapping. We proposed a scheme for including different quality measures in manual mapping. This might be useful for evaluating the reliability of manual mapping as reference data, even if some of these measures are subjective and rely on the interpreter. On the other hand, the OBIA approach is more transparent due to the use of replicable classification rules, but the expert knowledge required for the mapping of complex landslides or landslides that are partly covered by vegetation is difficult to implement in automated mapping workflows. Semi-automated landslide mapping approaches show high potential and would find even more acceptance if a set of generally agreed quality indicators and accuracy thresholds for the validation of EO-based landslide maps were commonly used.

Acknowledgments: This research has been supported by the Austrian Research Promotion Agency FFG in the Austrian Space Applications Program (ASAP 11) through the project "Land@Slide" (contract no: 847970).

Author Contributions: Daniel Hölbling had the idea for the paper and performed the object-based landslide mapping for study areas I, II, and V. Clemens Eisank did the OBIA mapping for study areas IV and V and calculated the spatial accuracy values. Florian Albrecht contributed to the accuracy assessment and the interpretation of results. Filippo Vecchiotti performed the visual landslide interpretation and provided the geological background information. Barbara Friedl wrote major parts of the introduction and contributed to the discussion. Elisabeth Weinke revised the manuscript and contributed to the discussion and conclusion. Arben Kociu provided valuable background information and revised the manuscript. All authors contributed to writing the paper.

Conflicts of Interest: The authors declare no conflict of interest. The founding sponsors had no role in the design of the study; in the collection, analyses, or interpretation of data; in the writing of the manuscript; or in the decision to publish the results. 


\section{References}

1. Van Westen, C.J.; Castellanos, E.; Kuriakose, S.L. Spatial data for landslide susceptibility, hazard, and vulnerability assessment: An overview. Eng. Geol. 2008, 102, 112-131. [CrossRef]

2. Scaioni, M.; Longoni, L.; Melillo, V.; Papini, M. Remote Sensing for Landslide Investigations: An Overview of Recent Achievements and Perspectives. Remote Sens. 2014, 6, 9600-9652. [CrossRef]

3. Singhroy, V. Remote sensing of landslides. In Landslide Hazard and Risk; Glade, T., Anderson, M.G., Crozier, M.J., Eds.; Wiley \& Sons: West Sussex, UK, 2005; pp. 469-492. ISBN 9780471486633.

4. Fiorucci, F.; Cardinali, M.; Carlà, R.; Rossi, M.; Mondini, A.C.; Santurri, L.; Ardizzone, F.; Guzzetti, F. Seasonal landslide mapping and estimation of landslide mobilization rates using aerial and satellite images. Geomorphology 2011, 129, 59-70. [CrossRef]

5. Gao, J.; Maro, J. Topographic controls on evolution of shallow landslides in pastoral Wairarapa, New Zealand, 1979-2003. Geomorphology 2010, 114, 373-381. [CrossRef]

6. Morgan, J.L.; Gergel, S.H.; Coops, N.C. Aerial Photography: A Rapidly Evolving Tool for Ecological Management. BioScience 2010, 60, 47-59. [CrossRef]

7. Galli, M.; Ardizzone, F.; Cardinali, M.; Guzzetti, F.; Reichenbach, P. Comparing landslide inventory maps. Geomorphology 2008, 94, 268-289. [CrossRef]

8. Hölbling, D.; Friedl, B.; Eisank, C. An object-based approach for semi-automated landslide change detection and attribution of changes to landslide classes in northern Taiwan. Earth Sci. Inform. 2015, 8, 327-335. [CrossRef]

9. Guzzetti, F.; Mondini, A.C.; Cardinali, M.; Fiorucci, F.; Santangelo, M.; Chang, K.-T. Landslide inventory maps: New tools for an old problem. Earth-Sci. Rev. 2012, 112, 42-66. [CrossRef]

10. Van Coillie, F.M.B.; Gardin, S.; Anseel, F.; Duyck, W.; Verbeke, L.P.C.; De Wulf, R.R. Variability of operator performance in remote-sensing image interpretation: The importance of human and external factors. Int. J. Remote Sens. 2014, 35, 754-778. [CrossRef]

11. Albrecht, F.; Lang, S.; Hölbling, D. Spatial accuracy assessment of object boundaries for object-based image analysis. In Proceedings of the GEOBIA 2010 - Geographic Object-Based Image Analysis, Ghent, Belgium, 29 June-2 July 2010; Addink, E., Van Coillie, F.M.B., Eds.; ISPRS Vol. No. XXXVIII-4/C7, Archives ISSN No $1682-1777$.

12. Kohli, D.; Stein, A.; Sliuzas, R. Uncertainty analysis for image interpretations of urban slums. Comput. Environ. Urban Syst. 2016, 60, 37-49. [CrossRef]

13. Guzzetti, F.; Cardinali, M.; Reichenbach, P.; Carrara, A. Comparing Landslide Maps: A Case Study in the Upper Tiber River Basin, Central Italy. Environ. Manag. 2000, 25, 247-263. [CrossRef]

14. Ardizzone, F.; Cardinali, M.; Carrara, A.; Guzzetti, F.; Reichenbach, P. Impact of mapping errors on the reliability of landslide hazard maps. Nat. Hazards Earth Syst. Sci. 2002, 2, 3-14. [CrossRef]

15. Moosavi, V.; Talebi, A.; Shirmohammadi, B. Producing a landslide inventory map using pixel-based and object-oriented approaches optimized by Taguchi method. Geomorphology 2014, 204, 646-656. [CrossRef]

16. Stumpf, A.; Kerle, N. Object-oriented mapping of landslides using Random Forests. Remote Sens. Environ. 2011, 115, 2564-2577. [CrossRef]

17. Martha, T.R.; Kerle, N.; Jetten, V.; van Westen, C.J.; Kumar, K.V. Characterising spectral, spatial and morphometric properties of landslides for semi-automatic detection using object-oriented methods. Geomorphology 2010, 116, 24-36. [CrossRef]

18. Barlow, J.; Franklin, S.; Martin, Y. High spatial resolution satellite imagery, DEM derivatives, and image segmentation for the detection of mass wasting processes. Photogramm. Eng. Rem. S. 2006, 72, 687-692. [CrossRef]

19. Behling, R.; Roessner, S.; Kaufmann, H.; Kleinschmit, B. Automated Spatiotemporal Landslide Mapping over Large Areas Using RapidEye Time Series Data. Remote Sens. 2014, 6, 8026-8055. [CrossRef]

20. Blaschke, T.; Feizizadeh, B.; Hölbling, D. Object-Based Image Analysis and Digital Terrain Analysis for Locating Landslides in the Urmia Lake Basin, Iran. IEEE J. Sel. Top. Appl. 2014, 7, 4806-4817. [CrossRef]

21. Heleno, S.; Matias, M.; Pina, P.; Sousa, A.J. Semiautomated object-based classification of rain-induced landslides with VHR multispectral images on Madeira Island. Nat. Hazards Earth Syst. Sci. 2016, 16, 1035-1048. [CrossRef] 
22. Hölbling, D.; Füreder, P.; Antolini, F.; Cigna, F.; Casagli, N.; Lang, S. A Semi-Automated Object-Based Approach for Landslide Detection Validated by Persistent Scatterer Interferometry Measures and Landslide Inventories. Remote Sens. 2012, 4, 1310-1336. [CrossRef]

23. Hölbling, D.; Betts, H.; Spiekermann, R.; Phillips, C. Identifying Spatio-Temporal Landslide Hotspots on North Island, New Zealand, by Analyzing Historical and Recent Aerial Photography. Geosciences 2016, 6, 48. [CrossRef]

24. Kurtz, C.; Stumpf, A.; Malet, J.-P.; Gançarski, P.; Puissant, A.; Passat, N. Hierarchical extraction of landslides from multiresolution remotely sensed optical images. ISPRS J. Photogramm. 2014, 87, 122-136. [CrossRef]

25. Lahousse, T.; Chang, K.-T.; Lin, Y. Landslide mapping with multiscale object-based image analysis-A case study in the Baichi watershed, Taiwan. Nat. Hazards Earth Syst. Sci. 2011, 11, 2715-2726. [CrossRef]

26. Lu, P.; Stumpf, A.; Kerle, N.; Casagli, N. Object-oriented change detection for landslide rapid mapping. IEEE Geosci. Remote Sens. 2011, 8, 701-705. [CrossRef]

27. Martha, T.R.; Kerle, N.; van Westen, C.J.; Jetten, V.; Kumar, K.V. Segment Optimization and Data-Driven Thresholding for Knowledge-Based Landslide Detection by Object-Based Image Analysis. IEEE Geosci. Remote Sens. 2011, 49, 4928-4943. [CrossRef]

28. Martha, T.R.; Kerle, N.; van Westen, C.J.; Jetten, V.; Kumar, K.V. Object-oriented analysis of multi-temporal panchromatic images for creation of historical landslide inventories. ISPRS J. Photogramm. 2012, 67, 105-119. [CrossRef]

29. Rau, J.-Y.; Jhan, J.-P.; Rau, R.-J. Semiautomatic object-oriented landslide recognition scheme from multisensor optical imagery and DEM. IEEE Trans. Geosci. Remote Sens. 2014, 52, 1336-1349. [CrossRef]

30. Lang, S. Object-based image analysis for remote sensing applications: modeling reality-Dealing with complexity. In Object-Based Image Analysis; Blaschke, T., Lang, S., Hay, G.J., Eds.; Springer: Heidelberg/Berlin, Germany; New York, NY, USA, 2008; pp. 1-25. ISBN 978-3-540-77058-9.

31. Eisank, C.; Hölbling, D.; Friedl, B.; Chen, Y.C.; Chang, K.T. Expert knowledge for object-based landslide mapping in Taiwan. South-East. Eur. J. Earth Obs. Geomat. 2014, 3, 347-350.

32. Wagreich, M.; Lukeneder, A.; Egger, H. Cretaceous History of Austria. In Proceedings of the International Meeting on Correlation of Cretaceous Micro-And Macrofossils-Berichte der Geologischen Bundesanstalt, Vienna, Austria, 16-18 April 2008; Volume 74, pp. 12-30.

33. Vecchiotti, F.; Kociu, A. Geohazard Description for Salzburg, Public Pangeo FP7 Final Report, 2013. Available online: http:/ / www.pangeoproject.eu/eng/coverage_map (accessed on 30 March 2017).

34. Embleton-Hamann, C. Geomorphological hazards in Austria. In Geomorphology for the Future; Kellerer-Pirklbauer, A., Keiler, M., Embleton-Hamann, C., Stötter, J., Eds.; Innsbruck University Press: Innsbruck, Austria, 2007; pp. 33-56; ISBN 978-3-902571-18-2.

35. Fiebiger, G. Die Rutschung Fürwag im Norden von Salzburg/Österreich. Prozess und Maßnahmen. In Proceedings of the International Congress Interpraevent, Matsumoto, Japan, 14-18 October 2002; pp. 629-639.

36. Friebe, J.G. Geologie der Österreichischen Bundesländer. Vorarlberg. Erläuterungen der Geologischen Karte Vorarlberg 1:100,000; Geologische Bundesanstalt: Vienna, Austria, 2007.

37. Seijmonsbergen, A.C.; Anders, N.; Bouten, W. Geomorphological change detection using object-based feature extraction from multi-temporal LiDAR data. In Proceedings of the 4th GEOBIA, Rio de Janeiro, Brazil, 7-9 May 2012; Feitosa, R., Costa, G., Almeida, C., Eds.; pp. 484-489.

38. Dorren, L.K.; Maier, B.; Seijmonsbergen, A.C. Improved Landsat-based forest mapping in steep mountainous terrain using object-based classification. Forest Ecol. Manag. 2003, 183, 31-46. [CrossRef]

39. De Graaff, L.W.S.; Seijmonsbergen, A.C. Postglacial landslides and their impact on Pleistocene lake floor deposits in the Balderschwang Valley as witnessed by geomorphological, sedimentological and geophysical evidence (Vorarlberg, Austria). Vorarlb. Naturschau 2001, 9, 237-251.

40. Ghuffar, S.; Szekely, B.; Roncat, A.; Pfeifer, N. Landslide Displacement Monitoring Using 3D Range Flow on Airborne and Terrestrial LiDAR Data. Remote Sens. 2013, 5, 2720-2745. [CrossRef]

41. Jaritz, W.; Supper, R.; Wöhrer-Alge, M. Beurteilung geogener Gefahren in Hinblick auf eine Risikominderung in der Gemeinde Sibratsgfäll (Österreich). In Proceedings of the 11th Interpraevent Congress, Dornbirn, Austria, 26-30 May 2008; pp. 171-182. 
42. Brandner, R.; Gruber, A.; Morelli, C.; Mair, V. Field trip 1-Pulses of Neotethys-Rifting in the Permomesozoic of the Dolomites. In Geo.Alp; Institute of Geology-University of Innsbruck: Innsbruck, Austria, 2016; Volume 13, pp. 7-70.

43. Gianolla, P.; Andreetta, R.; Furin, S.; Furlanis, S.; Riva, A. Geology of the Dolomites. In Nomination of the Dolomites for Inscription on the World Natural Heritage List Unesco; Artimedia: Trento, Italy, 2008; pp. 3-77.

44. Larcher, V.; Notarnicola, C.; Piacentini, D.; Pinter, T.; Schneiderbauer, S.; Soldati, M.; Strada, C. Analyse flachgründiger Massenbewegungen mittels Verwendung zweier statistischer Methoden im Gadertal (Südtirol). In Proceedings of the COGeo, Salzburg, Austria, 11 June 2010; Marschallinger, R., Wanker, W., Zobl, F., Eds.; pp. 1-11.

45. Corsini, A.; Pasuto, A.; Soldati, M.; Zannoni, A. Field monitoring of the Corvara landslide (Dolomites, Italy) and its relevance for hazard assessment. Geomorphology 2005, 66, 149-165. [CrossRef]

46. Riley, S.J.; De Gloria, S.D.; Elliot, R. A terrain ruggedness that quantifies topographic heterogeneity. Interm. J. Sci. 1999, 5, 23-27.

47. Tilch, N. Identifizierung gravitativer Massenbewegungen mittels multitemporaler Luftbildauswertung in Vorarlberg und angrenzender Gebiete. Jahrb. Geol. Bundesanstalt 2014, 154, 21-39.

48. Kociu, A.; Kautz, H.; Tilch, N.; Grösel, K.; Horst, H.; Reischer, J. Massenbewegungen in Österreich. Jahrb. Geol. Bundesanstalt 2007, 147, 215-220.

49. Wills, C.J.; McCrink, T.P. Comparing Landslide Inventories: The Map Depends on the Method. Environ. Eng. Geosci. 2002, 8, 279-293. [CrossRef]

50. Hungr, O.; Leroueil, S.; Picarelli, L. The Varnes classification of landslide types, an update. Landslides 2014, 11, 167-194. [CrossRef]

51. Cruden, D.M.; Varnes, D.J. Landslide Types and Processes. In Landslides: Investigation and Mitigation; Turner, A.K., Schuster, R.L., Eds.; Sp. Rep. 247; Transportation Research Board, National Research Council, National Academy Press: Washington, DC, USA, 1996; pp. 36-75. ISBN 978-0309062084.

52. Congalton, R.G.; Green, K. Assessing the Accuracy of Remotely Sensed Data-Principles and Practices, 2nd ed.; CRC Press: Boca Raton, FL, USA, 2008; p. 183. ISBN 978-1420055122.

53. Foody, G.M. Status of land cover classification accuracy assessment. Remote Sens. Environ. 2002, 80, $185-201$. [CrossRef]

54. Pontius, R.G.; Millones, M. Death to Kappa: Birth of quantity disagreement and allocation disagreement for accuracy assessment. Int. J. Remote Sens. 2011, 32, 4407-4429. [CrossRef]

55. Eisank, C.; Smith, M.; Hillier, J. Assessment of multiresolution segmentation for delimiting drumlins in digital elevation models. Geomorphology 2014, 214, 452-464. [CrossRef] [PubMed]

56. Clinton, N.; Holt, A.; Scarborough, J.; Yan, L.; Gong, P. Accuracy Assessment Measures for Object-based Image Segmentation Goodness. Photogramm. Eng. Rem. S. 2010, 76, 289-299. [CrossRef]

57. Belgiu, M.; Draguț, L. Comparing supervised and unsupervised multiresolution segmentation approaches for extracting buildings from very high resolution imagery. ISPRS J. Photogramm. 2014, 96, 67-75. [CrossRef] [PubMed]

58. Lang, S.; Albrecht, F.; Kienberger, S.; Tiede, D. Object validity for operational tasks in a policy context. J. Spat. Sci. 2010, 55, 9-22. [CrossRef]

59. Hölbling, D.; Betts, H.; Spiekermann, R.; Phillips, C. Semi-automated landslide mapping from historical and recent aerial photography. In Proceedings of the 19th AGILE Conference on Geographic Information Science, Helsinki, Finland, 14-17 June 2016; p. 5.

60. Hölbling, D.; Eisank, C.; Friedl, B.; Weinke, E.; Kleindienst, H.; Kociu, A.; Vecchiotti, F.; Albrecht, F. EO-based landslide mapping: From methodological developments to automated web-based information delivery. In Proceedings of the 13th Congress Interpraevent-Extended Abstracts, Lucerne, Switzerland, 30 May-2 June 2016; pp. 102-103.

61. Weinke, E.; Albrecht, F.; Hölbling, D.; Eisank, C.; Vecchiotti, F. Verfahren zur Implementierung eines Kartierungsdienstes für Rutschungen auf Basis von Fernerkundungsdaten und Nutzereinbindung. AGIT J. Angew. Geoinform. 2016, 46-55. [CrossRef]

(C) 2017 by the authors. Licensee MDPI, Basel, Switzerland. This article is an open access article distributed under the terms and conditions of the Creative Commons Attribution (CC BY) license (http:/ / creativecommons.org/licenses/by/4.0/). 